\title{
PENERAPAN INOVASI PELAYANAN PUBLIK SAMSAT KELILING DI KOTA TASIKMALAYA
}

\author{
Ari Ramdani \\ STIA YPPT Priatim Tasikmalaya \\ ari_ramdani1983@yahoo.co.id
}

\begin{abstract}
Abstrak
Penelitian ini berjudul Inovasi Pelayanan Publik SAMSAT Keliling Di Kota Tasikmalaya, yang dilatar belakangi oleh permasalahan berupa kebutuhan layanan administratif SAMSAT begitu besar menyebabkan antrian panjang ataupun penuh sesak sehingga berimbas pada lamanya masyarakat harus menunggu untuk mendapatkan layanan tersebut. Permasalahan tersebut penulis teliti terkait bagaimana penerapan Inovasi Pelayanan Publik SAMSAT Keliling dengan mempergunakan pendekatan kuantitatif dengan metode deskriptif dengan responden masyarakat Kota Tasikmalaya yang mendapatkan pelayanan dari SAMSAT Keliling. Adapun hasil dari penelitian tersebut menunjukkan bahwa penerapan inovasi pelayanan publik SAMSAT Keliling Di Kota Tasikmalaya berjalan dengan baik dengan dijalankannya 3 indikator inovasi pelayanan publik.

\section{Kata Kunci: Inovasi, Pelayanan Publik}

Abstract

This research entitled The Innovation of Public Service of SAMSAT in Tasikmalaya City, based on the problem of the need for the administrative services of SAMSAT is so big that it causes long queue or overcrowded so that the duration of society have to wait to get the service. The problem is pneulis meticulously related how the implementation of Public Service Innovation SAMSAT Roving by using a quantitative approach with descriptive methods with respondents Tasikmalaya City community who get the services of SAMSAT Roving. The results of this study indicate that the implementation of public service innovation SAMSAT Roving In Tasikmalaya City run well with the implementation of 3 indicators of innovation public service.
\end{abstract}

Keywords: Innovation, Public Service

\section{A. PENDAHULUAN}

Sebagai sebuah negara berbentuk Republik, Indonesia secara konstitusional mempunyai tujuan yang hendak direalisasikan dalam jangka panjang yaitu mewujudkan kesejahteraan masyarakat adil dan makmur. Implikasi dari hal tersebut, memberikan gambaran bahwa negara memiliki kewajiban yang harus ditunaikan kepada warganya dalam pemenuhan kebutuhan hidupnya di berbagai lini bidang kehidupan melalui pelayanan publik.

Pelayanan publik merupakan hal terpenting dalam perwujudan tujuan negara.
Pelayanan publik memiliki peranan penting dalam meningkatkan kesejahteraan masyarakat di berbagai bidang baik itu bidang pendidikan, ekonomi, kesehatan, keamanan, infrastruktur, dll. Semakin baik pelayanan publik yang diberikan maka akan sebanding lurus dengan tingkat kesejahteraan masyarakatnya. Banyak contoh negara di luar Indonesia yang sudah membuktikan akan hal tersebut.

Lain halnya dengan kondisi di negara kita, pelayanan publik masih jauh dari apa yang diharapkan. Masih banyak pekerjaan rumah 
yang harus diselesaikan pemerintah pusat maupun daerah dalam penyelenggaraan pelayanan publik di berbagai bidang kehidupan baik itu pelayanan dalam bentuk barang, jasa, maupun yang bersifat administratif.

Masih banyak ditemui berbagai keluhan dari masyarakat akan kualitas pelayanan publik yang diberikan. Mulai dari prosedur yang terlalu ribet, antrian yang panjang dalam pelayanan, sarana prasarana pelayanan yang tidak memadai, penumpukan masyarakat yang ingin mendapatkan pelayanan dalam satu instansi, sampai dengan adanya pungutan liar atau pungli bahkan calo dalam proses palayanan publik. Tentunya ini beberapa temuan saja yang secara general kerap terjadi di berbagai wilayah di Indonesia.

Permasalahan ini merupakan tanggung jawab dari pemerintah yang harus segera diselesaikan, tidak hanya Pemerintah Pusat saja, melainkan Pemerintah daerah pula. Sebab di era otonomi daerah, substansinya pelayanan publik diberikan secara desentralistis tidak sentralistik kecuali dalam pelayanan publik dalam hal-hal tertentu saja.

Apa yang terjadi di daerah pun relatif sama jikalau berbagai pelayanan publik terutama pelayanan publik yang bersifat administratif.

Pemerintah Kota Tasikmalaya salah satunya. Dengan jumlah penduduk yang begitu banyak tentunya kebutuhan akan pelayanan publik yang bersifat administratif pun besar pula. Salah satunya adalah pelayan publik yang diselenggarakan oleh Kantor Sistem Administrasi Manunggal Satu Atap (SAMSAT) Kota Tasikmalaya. Kantor SAMSAT Kota Tasikmalaya inilah yang senantiasa tidak penah sepi dan tidak hentinya dalam memberikan pelayanan publik administratif, mulai dari pembuatan STNK, Bea Balik Nama Kendaraan Bermotor, Perpanjangan atau pembayaran pajak kendaraan bermotor setiap harinya. Sehingga terkadang dengan animo masyarakat akan kebutuhan tersebut begitu besar menyebabkan antrian panjang ataupun penuh sesak sehingga berimbas pada lamanya masyarakat harus menunggu untuk mendapatkan layanan tersebut. Sehingga sebagai upaya untuk mengatasi itu semua, maka dilakukan lah sebuah inovasi pelayanan publik berupa samsat keliling, SAMSAT keliling ini melayani pengesahan STNK/Pembayaran Pajak. Pelayanan SAMSAT keliling dilakukan melalui Bus SAMSAT Keliling yang memiliki tujuan untuk mendekatkan dan memudahkan pelayanan kepada masyarakat, terutama yang memiliki tingkat kesibukan yang tinggi, karena merasa kekurangan waktu bila datang mengurus ke Kantor Bersama SAMSAT, maka dengan adanya Bus SAMSAT Keliling masyarakat Wajib Pajak akan sangat terbantu mempersingkat waktu dalams pengurusan Pengesahan STNK/Pembayaran Pajak Kendaraan Bermotor.

Dengan berlatar belakang penelitian itulah, penulis tertarik untuk mengambil judul penelitian, "Penerapan Inovasi Pelayanan Publik SAMSAT Keliling di Kota Tasikmalaya".

\section{Tinjauan Pustaka \\ Konsep Pelayanan Publik}

Berdasarkan apa yang tertulis dalam Kamus Besar Bahasa Indonesia bahwa apa yang dinamakan sebagai pelayanan adalah sebagai hal, cara atau hasil pekerjaan melayani. Sedangkan melayani adalah menyuguhi orang dengan makanan atau minuman; menyediakan keperluan orang; mengiyakan; menerima; menggunakan. Sedangkan kata Publik berasal dari bahasa Inggris yaitu public yang memiliki makna umum, masyarakat, negara atau orang banyak. Sedangkan dalam serapan Bahasa Indonesia, makna publik adalah umum, orang banyak, ramai. Elaborasi terminologi diatas pada akhirnya memberikan dasar pengertian terhadap konsep pelayanan publik.

Berdasarkan Undang-Undang No 25 Tahun 2009, bahwa apa yang disebut sebagai pelayanan publik adalah, "kegiatan atau rangkaian kegiatan dalam rangka pemenuhan 
kebutuhan pelayanan sesuai dengan peraturan perundang-undangan bagi setiap warga Negara dan penduduk atas barang, jasa, dan atau pelayanan administrative yang disediakan oleh penyelenggara pelayanan publik."

Dari definisi tersebut diatas dapat dipahami bahwa pelayanan publik berbicara penyelenggara pelayanan dalam hal ini tentunya Pemerintah dan penerima penyelenggara yaitu publik dalam arti warga Negara atau penduduk. Adapun pelayanan yang diberikan meliputi pelayanan dalam berbentuk barang, jasa ataupun yang berifat administrative.

Kemudian pelayanan publik yang diberikan tentunya diatur melalui regulasiregulasi tertentu sesuai dengan tingkat kebutuhan layanan. Pelayanan Publik yang diberikan oleh SAMSAT Keliling merupakan salah satu pelayanan publik yang bersfiat administrative dalam rangka pemenuhan kebutuhan masyarakat. Menurut Sinambela (2011:5) pelayanan publik adalah pemenuhan keinginan dan kebutuhan masyarakat oleh penyelenggara negara.

\section{Inovasi}

Dalam PerMenPan No 30 Tahun 2014 Tentang Pedoman Inovasi Pelayanan Publik, bahwa apa yang dinamakan sebagai inovasi adalah proses kreatif penciptaan pengetahuan dalam melakukan penemuan baru yang berbeda dan atau modifikasi dari yang sudah ada. Inovasi merupakan sebuah ide, praktek atau objek yang dianggap baru oleh individu satu unit dan diadopsi oleh unit lainnya. (Everett M Rogers dalam Suwarno: 2014)

Inovasi adalah kegiatan yang meliputi seluruh proses menciptakan dan menawarkan jasa atau barang baik yang sifatnya baru, labih baik atau lebih murah dibandingkan dengan yang tersedia sebelumnnya. (Bussiness 1000 dalam Suwarno:2014). Sedangkan menurut Widodo (2017:5), inovasi adalah penyederhanaan dan atau pengintegrasian tata laksana (business process).
Sebuah Inovasi dapat berupa produk atau jasa yanag baru, teknologi proses produksi yang baru, system struktur dan administrasi baru ata rencana baru bagi anggota (Fariborz dalam Suwarno, 2014)

Inovasi itu tidak perlu besar-besar, melainkan kecil-kecil atau tidak muluk-muluk, tetapi memberikan dan menjadi sebuah solusi dalam pelayanan khususnya.

Hal ini senada dengan apa yang disampaikan oleh Widodo (2017:25), bahwa inovasi itu memiliki karakteristik yaitu: 1). Ada tidaknya dampak positif atau kemamfaatan dari suatu inisiatif perubahan. 2). Mampu member solusi terhadap masalah, 3). Inovasi juga haruslah berkesinambungan. Tiga karakteritik inilah yang harus melekat dalam Inovasi Pelayanan Publik sebagaimana yang akan dijelaskan di bawah ini.

\section{Inovasi Pelayanan Publik}

Dalam PerMenPan No 30 Tahun 2014 Tentang Pedoman Inovasi Pelayanan Publik bahwa,

"Inovasi pelayanan publik adalah terobosan jenis pelayanan baik yang merupakan gagasan/ide kreatif orisinal dan atau adaptasi/modifikasi yang memberikan mamfaat bagi masyarakat, baik secara langsung maupun tidak langsung. Dengan kata lain, inovasi pelayanan publik sendiri tidak mengharuskan penemuan baru, tetapi dapat merupakan suatu pendekatan baru yang bersifat kontekstual dalam arti inovasi tidak terbatas dari tidak ada kemudian muncul gagasan dan praktik inovasi, tetapi dapat berupa inovasi hasil dari perluasan maupun peningkatan dan kualitas pada inovasi yang ada."

Hal ini senada dengan apa yang disampaikan oleh Widodo (2017:25), bahwa inovasi itu memiliki karakteristik yaitu: 1). Ada tidaknya dampak positif atau kemamfaatan dari suatu inisiatif perubahan. 2). Mampu member solusi terhadap masalah, 3). Inovasi juga haruslah berkesinambungan. 


\section{Kerangka Pemikiran}

Dari uraian di atas maka, dibuatlah kerangka pemikiran sebagai berikut:

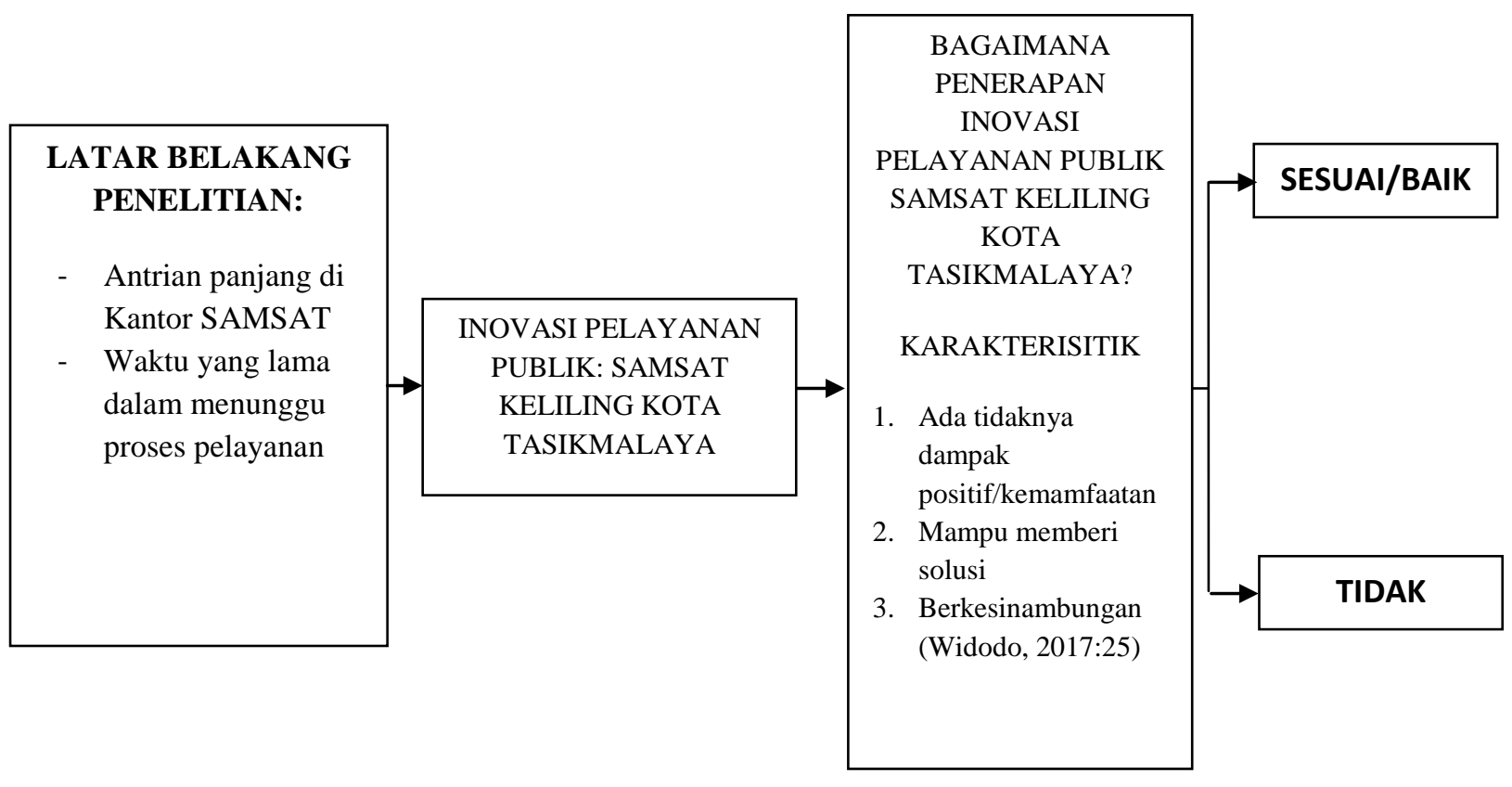

\section{B. METODE PENELITIAN}

Metode penelitian yang digunakan dalam penelitian ini adalah penelitian deskriptif dengan pendekatan kuantitatif. Menurut Zuriah (2006:47) penelitian dengan menggunakan metode deskriptif adalah, "penelitian yang diarahkan untuk memberikan gejala-gejala, fakta-fakta atau kejadiankejadian secara sistematis dan akurat, mengenai sifat-sifat populasi daerah tertentu. Dalam penelitian deskriptif cenderung tidak perlu mencari atau menerangkan saling berhubungan dengan menguji hipotesis."

Sedangkan populasi dalam penelitian penerapan inovasi pelayanan publik SAMSAT keliling ini adalah Masyarakat Kota Tasikmalaya yang pernah mendapatkan atau menggunakan pelayanan SAMSAT keliling. Sampel adalah bagian dari jumlah dan karakteristik yang dimiliki oleh populasi tersebut (Sugiyono, 2006;91). Teknik sampling yang dipergunakan adalah teknik pengambilan sample melalui aplikasi google form yang link form nya di share ke media sosial whatsapp grup yang ada dan di isi oleh orang-orang atau masyarakat Kota
Tasikmalaya yang pernah mendapatkan atau menggunakan layanan SAMSAT Keliling.

Teknik pengumpulan data yang dipergunakan dalam penelitian ini adalah : Observasi, wawancara dan Angket.

\section{Rancangan Analisis Data}

Peneliti menggunakan metode kuantitatif deskriptif dalam menganalisis data. Data yang diperoleh melalui angket diprosentasikan sesuai dengan masingmasing jawaban dari tiap-tiap item pertanyaan/pernyataan yang tertuang dalam angket. Kemudian dijelaskan dan disinkronisasikan dengan hasil observasi dan wawancara.

\section{HASIL PENELITIAN DAN PEMBAHASAN}

Pelayanan publik merupakan hal yang sangat penting bagi sebuah pemerintahan dalam mewujudkan kesejahteraan masyarakat. Sehingga wajar saja kalau pelayanan publik merupakan cerminan kesungguhan pemerintah dalam memenuhi kebutuhan masyarakat. Namun bukan rahasia umum lagi, bahwa pelayanan publik selama 
ini jauh dari apa yang diharapkan oleh masyarakat. Tak terkecuali dalam pelayanan administratif diantaranya adalah pelayanan yang diberikan oleh kantor SAMSAT Kota Tasikmalaya. Pelayanan yang diberikan oleh kantor SAMSAT ini merupakan salah satu pelayanan administratif yang yang senantiasa jauh dari suasana sepi. Artinya setiap hari masyarakat begitu banyak yang membutuhkan pelayanan ini. Sehingga yang terjadi adalah penumpukan masyarakat yang membutuhkan pelayanan tsb di kantor SAMSAT. Oleh karena itu, dalam rangka mengatasi hal tsb kantor SAMSAT melakukan sebuah inovasi pelayanan publik berupa SAMSAT Keliling. Hal ini diupayakan supaya memudahkan dan memperlancar masyarakat mendapatkan pelayanan, khususnya masyarakat Kota Tasikmalaya.

Tentunya sebuah tujuan inovasi pelayanan publik tersebut sesuai dengan apa yang diharapkan atau tidaknya, memerlukan sebuah jawaban dari para pengguna layanan tersebut yang dilihat dari sejauhmana penerapan inovasi pelayanan publik SAMSAT Keliling melalui tiga hal besar yaitu: 1). Ada tidaknya dampak positif atau kemamfaatan dari suatu inisiatif perubahan. 2). Mampu memberi solusi terhadap masalah, 3). Inovasi juga haruslah berkesinambungan.

Hal inilah yang penulis teliti untuk dibahas dalam bab ini. Namun sebelumnya penulis tuangkan hasil penelitian dari hasil jawaban angket dari 25 responden yang pernah mendapatkan pelayanan dari SAMSAT Keliling Kota Tasikmalaya.

\section{Hasil Penelitian}

Adapun hasil penelitian yang diperoleh dari tanggapan atau jawaban masyarakat terhadap penerapan inovasi pelayanan publik SAMSAT Keliling Kota Tasikmalaya adalah sebagai berikut.:

\section{Berdampak positif atau memberikan mamfaat.}

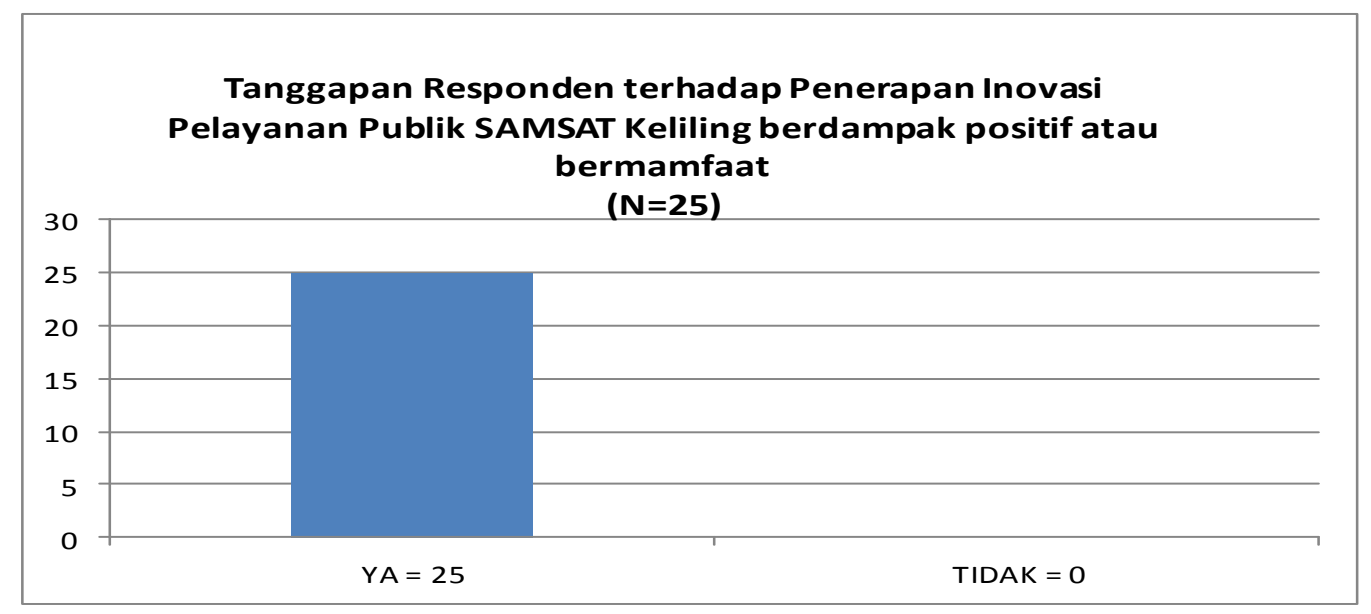




\section{Memberi solusi terhadap masalah}

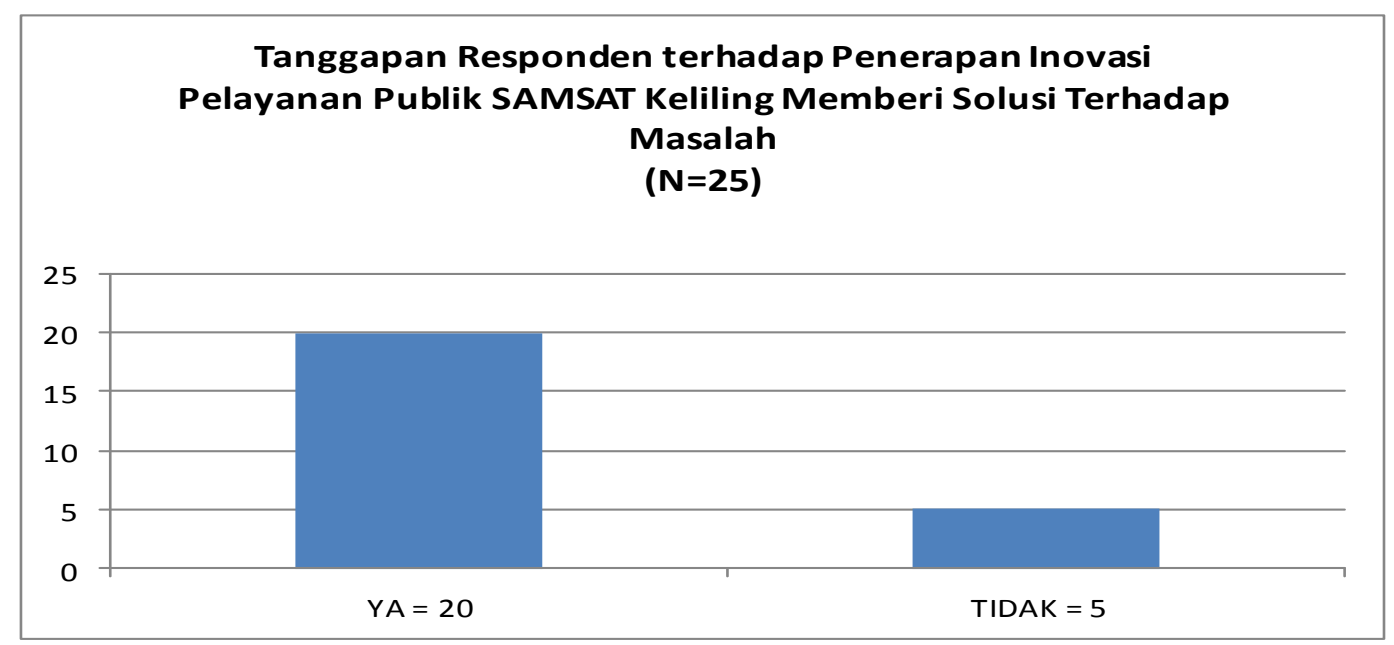

\section{Berkesinambungan}

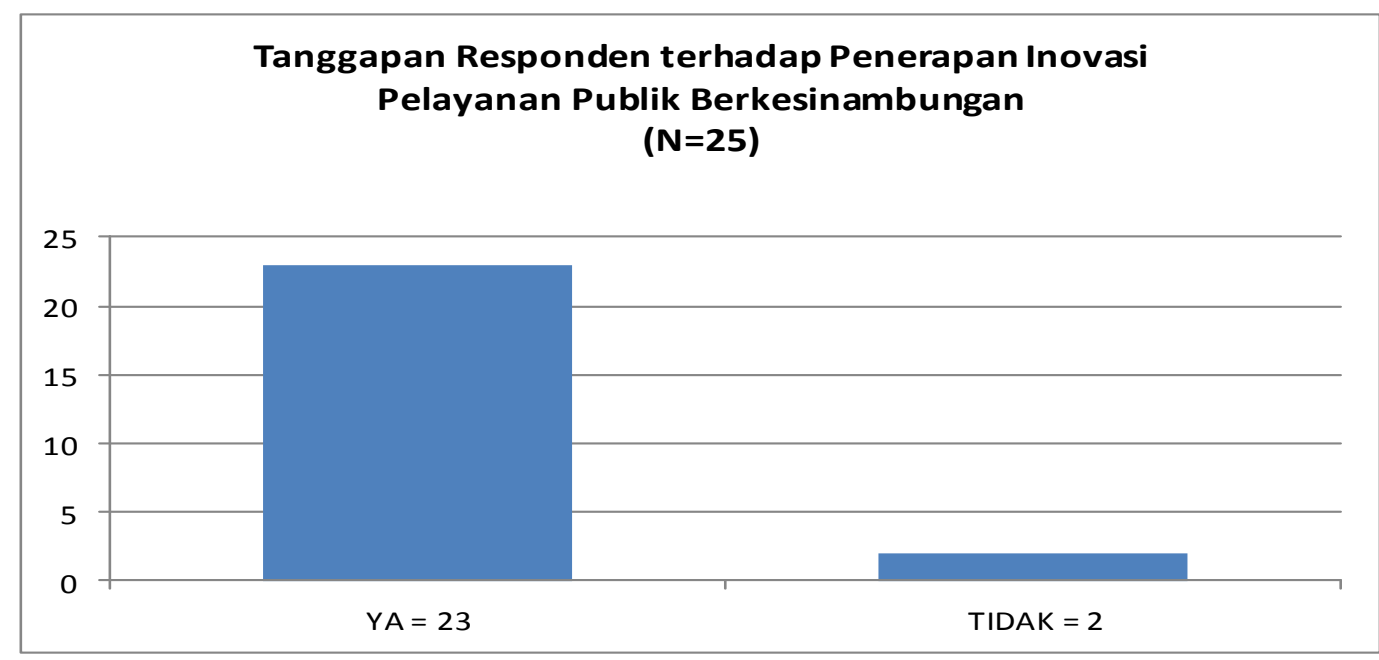

\section{Pembahasan}

Inovasi pelayanan publik merupakan solusi dari masalah pemberian pelayanan yang tidak dapat terpenuhi secara maksimal kepada masyarakat. Dalam inovasi ditutuntut kebaruan dalam memberikan pelayanan. Sehingga inovasi tersebut dapat mengurai permasalahan dalam pemberian pelayanan publik. Tak terkecuali pelayanan yang diberikan oleh SAMSAT Keliling Kota Tasikmalaya. SAMSAT Keliling merupakan sebuah inovasi yang telah memenuhi karakteristik inovasi iitu sendiri. Tetapi secara prakteknya apakah penerapan inovasi itu sudah berjalan sesuai dengan apa yang diharapkan?. Inilah yang menjadi fokus penelitian penulis untuk menjawab pertanyaan tersebut.

Penerapan Inovasi Pelayanan Publik SAMSAT Keliling di Kota Tasikmalaya di ukur melalui tiga karakteristik sebagai berikut. 


\section{Berdampak positif atau memberikan mamfaat}

Berdasarkan hasil pengolahan data dari 25 responden terhadap penerapan inovasi pelayanan publik SAMSAT Kelilig Di Kota Tasikmalaya berdampak positif atau memberikan mamfaat sebesar $100 \%$, artinya semua responden yang sebanyak 25 orang yang pernah mendapatkan pelayanan publik dari SAMSAT keliling sepakat menilai bahwa inovasi pelayanan publik SAMSAT Keliling Di Kota Tasikmalaya berdampak positif atau memberikan mamfaat. Hal ini diperkuat dengan hasil wawancara dengan beberapa responden,bahwa SAMSAT Keliling yang dilaksanakan di Kota Tasikmalaya memang sangatlah berdampak positif bagi SAMSAT sendiri. Hal ini ditunjukkan dengan pendapat responden yang mengatakan bahwa dengan adanya SAMSAT Keliling, menunjukkan bahwa SAMSAT sendiri bersunguh-sungguh melayani masyarakat secara optimal dan terbukti mampu mengurai penumpukan pelayanan jika harus diselesaikan di Kantor SAMSAT Kota Tasikmalaya sendiri.

SAMSAT Keliling ini pun dirasakan sangat memberikan mamfaat bagi masyarakat sendiri. Dari 25 responden memilih "YA", bahwa SAMSAT Keliling memberikan mamfaat, memiliki alasan yang relatif sama, bahwa masyarakat tidak perlu datang langsung ke kantor SAMSAT melainkan ke titik-titik mobil SAMSAT itu berada. Antrian tidak terlalu panjang, sehingga responden merasakan waktu yang sebentar atau tidak perlu menunggu lama untuk mendapatkan pelayanan administratif dari SAMSAT Kota Tasikmalaya melalui SAMSAT Keliling.

\section{Memberi solusi terhadap masalah}

Sebuah inovasi secara konseptual seharusnya sebuah inovasi merupakan sebuah solusi bagi sebuah permasalahan, dari yang buruk menjadi baik dan yang baik semakin baik. Apalagi dalam konteks pelayanan publik tentunya akan berujung pada kepuasan masyarakat akan layanan yang diberikan dan sekaligus membangun trust atau kepercayaan kepada pemarintah. Begitupula dalam Inovasi pelayanan publik berupa SAMSAT Keliling khususnya di Kota Tasikmalaya.

Dari hasil penelitian diatas yang tertuang dalam bentuk grafik bahwa sebanyak 20 responden menyatakan bahwa Inovasi pelayananpublik SAMSAT Keliling Di Kota Tasikmalaya merupakan sebuah solusi dalam mengurai penumpukan pelayanan di Kantor SAMSAT, serta menjadikan pelayanan admministratif SAMSAT dapat diakses oleh masyarakat secara mobile, artinya masyarakat pun tidak perlu datang ke kantor SAMSAT. Hal ini di perkuat dan di iyakan oleh petugas pemberi layanan SAMSAT Keliling di Kota Tasikmalaya.

Meskipun demikian masih ada 5 responden yang menyatakan bahwa inovasi pelayanan publik SAMSAT Keliling Kota Tasikmalaya belum bisa menjadi solusi terhdap masalah yang dihadapinya, karena menurutnya masih ada layanan yang tidak bisa diberikan secara mobile melalui SAMSAT Keliling ini, diantaranya adalah perpanjang STNK 5 Tahunan yang tetap mengharuskan masyarakat harus datang ke kantor SAMSAT langsung. Tetapi meskipun demikian, SAMSAT Keliling harus diakui setidaknya menjadi solusi terhadap masalahmasalah yang terjadi selama ini.

\section{Berkesinambungan}

Sebuah inovasi pelayanan publik tidak hanya harus berdampak positif saja dan menjadi solusi terhadap suatu masalah saja, melainkan harus pula berkesinambungan. Sehingga Penerapan Inovasi Pelayanan Publik SAMSAT Keliling Di Kota Tasikmalaya dapat berjalan dengan baik. Terkait dengan hal tersebut dari hasil penelitian didapatkan jawaban sebanyak 23 orang menyatakan bahwa SAMSAT Keliling dilakukan secara berkesinambungan artinya secara rutin, namun masih ada responden sebanyak 2 orang menyatakan sebaliknya. Tetapi berdasarkan apa yang penulis amati dan diperkuat dengan pernyataan petugas pemberi pelayanan SAMSAT Keliling Kota 
Tasikmalaya, bahwa SAMSAT Keliling dilaksanakan secara rutin. Ini menunjukkan bahwa penerapan inovasi pelayanan SAMSAT Keliling Di Kota Tasikmalaya sudah dilakukan secara berkesinambungan, artinya sudah dijalankan sesuai dengan karakteristik inovasi pelayanan publik itu sendiri.

\section{PENUTUP \\ Kesimpulan}

Berdasarkan hasil penelitian dan uraian pembahasan tersebut di atas, maka dapat disimpulkan bahwa Penerapan Inovasi Pelayanan Publik SAMSAT Keliling Di Kota Tasikmalaya dapat di katakan berjalan dengan baik, karena 3 kriteria dari karakteristik Inovasi Pelayanan Publik , 1). Ada tidaknya dampak positif atau kemamfaatan dari suatu inisiatif perubahan. 2). Mampu memberi solusi terhadap masalah, 3). Inovasi juga haruslah berkesinambungan, sudah diterapkan dalam pemberian pelayanan berupa layanan pengesahan STNK setiap tahun, pembayaran PKB dan SWDKLLJ kepada masyarakat.

\section{Saran}

Dari kesimpulan di atas yang menunjukkan bahwa Penerapan Inovasi Pelayanan Publik SAMSAT Keliling Di Kota Tasikmalaya sudah berjalan dengan baik atau sesuai dengan karakteristik inovasi pelayanan publik, maka saran dari penulis harus ditekankan dan menjadi prioritas bahwa karakteristik berkesinambungan dalam pelayanan SAMSAT Keliling di Kota Tasikmalaya tetap dipertahankan, karena masyarakat pengguna layanan SAMSAT Keliling akan semakin bertambah seiring dengan bertambahnya angka kepemilikan kendaraan bermotor.

\section{DAFTAR PUSTAKA}

Sinambela, Poltak. Reformasi Pelayanan Publik.Bumi Aksara. Jakarta, 2011.

Sugiyono, Metode Penelitian Administrasi. Alfabeta. Bandung, 2006.

Suwarno, Yogi. Inovasi Di Sektor Publik, Materi DIKLATPIM TINGKAT III, LAN-RI. 2014

Widodo, Tri. Inovasi Harga Mati. Rajawali Pers. Jakarta. 2017

Undang-Undang No 25 Tahun 2009 tentang Pelayanan Publik

PerMenPan No. 30 Tahun 2014 Tentang Pedoman Inovasi Pelayanan Publik 